\title{
EKSPOSISI MATIUS 2:1-12
}

Adi Putra, M.Th.

\section{Pengantar}

Injil Matius menjadi salah satu Injil dalam Perjanjian Baru yang selalu menarik untuk diekspos dan dianalisis. Mengapa? Oleh karena ada begitu banyak kejutan yang dapat dijumpai ketika membaca dan mencoba memahami Injil ini. Misalnya, selama ini dalam pemahaman kita; Injil Matius merupakan Injil yang sangat kental dengan sifat keyahudiannya. Akan tetapi setelah membaca dan menggalinya, ternyata juga di dalam narasinya dijumpai justru orang-orang non-Yahudi memiliki peran yang cukup sentral dalam sejarah pelayanan Tuhan Yesus seperti yang dicatatkan dalam Injil Matius. Apa yang dikemukakan di atas sejalan dengan pendapat Merril C. Tenney, yang mengatakan,

Tujuan dari Injil Matius adalah untuk menunjukkan bagaimana Yesus dari Nazaret mengembangkan serta menguraikan wahyu ilahi yang telah dimulai dalam nubuat tentang Mesias dalam Perjanjian Lama. Meskipun sifat dari kitab ini sangat berciri Yahudi, ia juga ditulis bagi kepentingan umat kafir, karena perintah-Nya yang terakhir adalah bagi kedua belas rasul untuk menjadikan "semua bangsa" muridmurid-Nya (28:19). ${ }^{1}$

Menambahkan apa yang telah dikemukakan oleh Tenney di atas, sebenarnya dalam kitab ini pula dijumpai banyak narasi yang menegaskan bahwa injil ini juga tidak mengesampingkan bangsa-bangsa non-Yahudi. Perhatikan bagan di bawah ini!

\begin{tabular}{|l|l|}
\hline 1. & $\begin{array}{l}\text { Matius 1:1-17 tentang Silsilah Yesus Kristus mencantumkan tiga wanita yang } \\
\text { sebenarnya bukan orang Yahudi, yakni: Rahab, Rut, istri Uria (Batsyeba). }\end{array}$ \\
\hline 2. & $\begin{array}{l}\text { Matius 2:1-12 tentang Orang Majus yang diberitahukan Tuhan tentang kelahiran } \\
\text { Yesus Kristus memberikan indikasi bahwa orang non-Yahudi pun memperoleh } \\
\text { anugerah. }\end{array}$ \\
\hline 3. & $\begin{array}{l}\text { Matius 8:5-13, tentang Yesus menyembuhkan hamba seorang perwira Romawi di } \\
\text { Kapernaum. }\end{array}$ \\
\hline 4. & $\begin{array}{l}\text { Matius 15: 21-28, tentang Yesus yang menyembuhkan anak perempuan Kanaan yang } \\
\text { kerasukan setan. Dari kisah ini mengindikasikan bahwa pelayanan-Nya ternyata juga } \\
\text { berdampak atau dirasakan manfaatnya orang-orang non-Yahudi. }\end{array}$ \\
\hline 5. & Matius 28:19, perintah untuk memberitakan Injil kepada "semua bangsa". \\
\hline 6. & $\begin{array}{l}\text { Apabila membaca Injil Matius, maka Injil ini sebenarnya menceritakan bahwa } \\
\text { selama melayani sekitar } 3 \text { tahun di bumi, Yesus banyak meluangkan waktu untuk } \\
\text { berada dan melayani di Galilea, wilayah bangsa-bangsa lain. }\end{array}$ \\
\hline
\end{tabular}

Dalam tulisan ini akan secara spesifik mengeksposisi Matius 2:1-12, yang mengisahkan ketaatan orang Majus terhadap petunjuk yang Tuhan berikan kepada mereka demi menyembah dan memuliakan Raja atau Mesias yang telah lahir di Bethlehem. Leon Morris mengatakan, "Sangat mungkin Matius memasukkan kisah orang Majus untuk menyingkapkan kebenaran bahwa Yesus adalah Tuhan atas semua orang; karena Yesus

\footnotetext{
${ }^{1}$ Merril C. Tenney, Survey Perjanjian Baru, Malang: Gandum Mas, 2006, hlm. 192.
} 
adalah Tuhan atas semua orang, adalah sesuai jika di saat kelahiran-Nya, orang-orang yang datang dari negeri yang jauh untuk memberikan penghormatan."2

Dengan demikian, perikop ini menjadi cukup menarik untuk diekspos dan dianalisis guna memahami maksud dan kehendak Tuhan melalui penulis Injil Matius memasukkan kisah ini dalam injilnya - di mana ketiga injil yang lain sama sekali tidak mencatatnya. Ada beberapa pertanyaan yang coba akan dijawab melalui penelitian atau tulisan ini, yakni: mengapa Yesus harus lahir di Bethelem, Tanah Yudea? Mengapa harus orang Majus? Mengapa Herodes berniat membunuh Yesus?

\section{Eksposisi Matius 2:1-12}

Dalam mengeksposisi perikop ini, akan dilaksanakan dengan tiga proses atau tahap, yakni mulai dengan tahap observasi, interpretasi dan aplikasi.

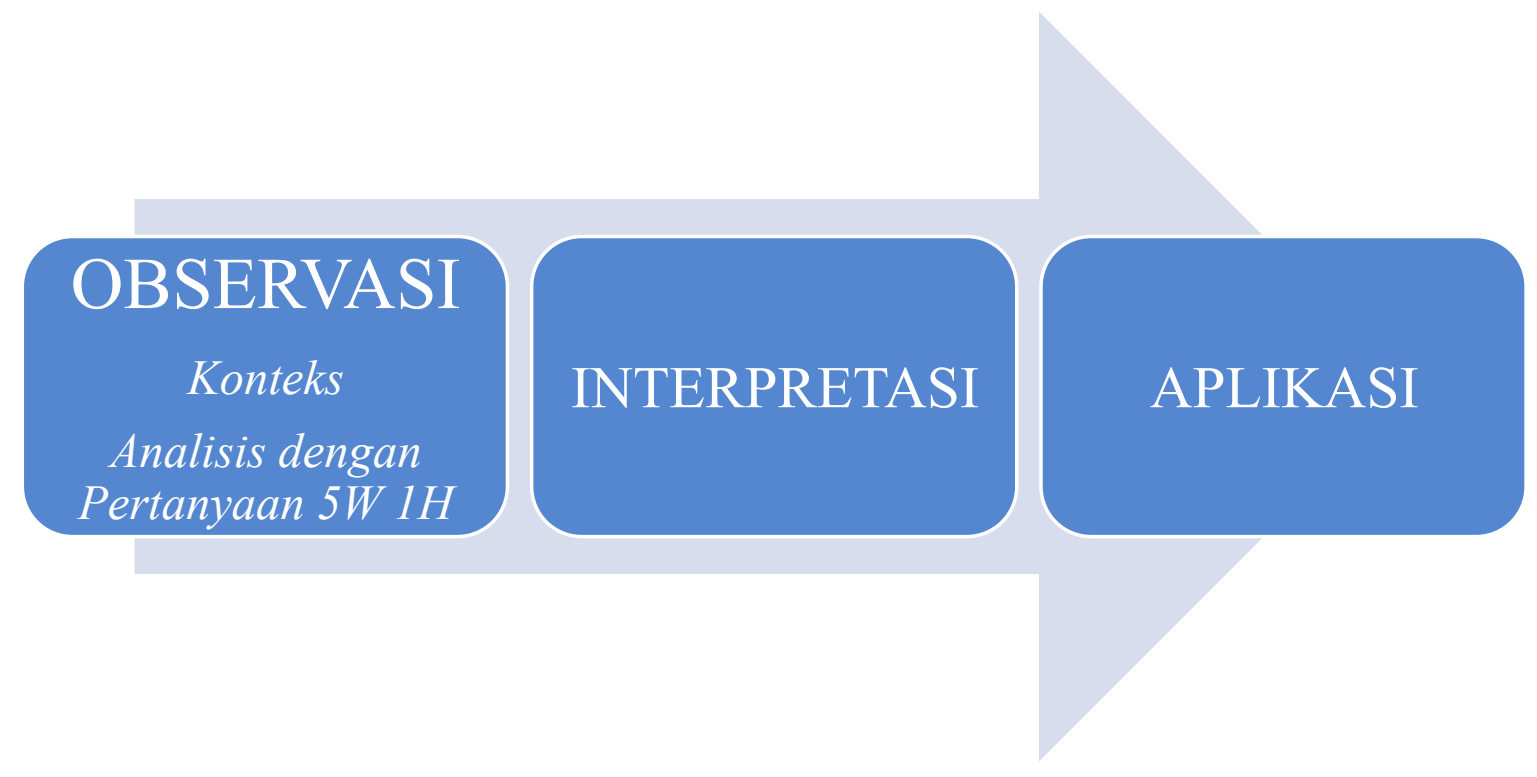

\section{Observasi}

Konteks Injil Matius. Penulis Injil Matius mencoba memperlihatkan bahwa kekristenan merupakan kelanjutan dari umat Allah yang adalah dalam PL. Apabila menyoroti penulisnya, maka di sana akan dijumpai bahwa dia adalah seorang Yahudi yang punya pengetahuan dan kompetensi yang cukup, bahkan juga akrab dengan pengajaran yang terdapat dalam Misnah dan Talmud. Bahkan ada juga beberapa penafsir yang mengatakan bahwa dia tidak anti terhadap penggunaan Midrash.

Penulis merupakan pengikut Yesus yang sejati, seorang Yahudi yang sudah menjadi percaya. Dalam injil ini, yang paling mencolok adalah penekanan kepada penggenapan nubuat-nubuat Perjanjian Lama - sekaligus menunjukkan identitas keyahudian penulis. ${ }^{3}$ Apabila memperhatikan dengan baik dan seksama, maka jelas sekali dalam contentnya,

\footnotetext{
${ }^{2}$ Leon Morris, Tafsiran Injil Matius, Surabaya: Momentum, 2016, hlm. 36-37.

${ }^{3}$ Injil Matius memiliki rumusan "Hal itu terjadi supaya genaplah yang difirmankan Tuhan oleh nabi", yang bahkan telah dijumpai sejak 1:22 dan muncul berulang-ulang kali di sepanjang Injil ini. Bahkan terdapat 61 kutipan PL dalam Injil Matius, sekaligus jumlah terbanyak apabila dibandingkan dengan injil yang lain (Markus 31 kutipan, Lukas 26 kutipan, dan Yohanes terdapat 16 kutipan).
} 
penulis begitu tertarik untuk menghubungkan apa yang dikemukakan dalam kitab-kitab PL dengan Yesus. Dan apabila memperhatikan setiap ayat-ayat PL yang dikutip, maka di sana jelas terlihat bahwa penulis ingin menunjukkan Allah sedang menggenapi maksudnya dan salah satu cara mengenali maksud Allah adalah dengan memperhatikan, bagaimana hal-hal yang Allah inspirasikan melalui para nabi-Nya telah tergenapi di dalam hidup dan pengajaran Yesus. Injil Matius diakhiri dengan mandat agung untuk memuridkan segala bangsa (28:1620). Sehingga, kemudian tidak keliru apabila dikatakan bahwa Injil Matius meskipun berlatar belakang Yahudi dan sangat tertarik dengan orang Yahudi, akan tetapi ia juga tertarik untuk merelevansikan Yesus bagi segala bangsa. ${ }^{4}$

Penerima tulisan Matius adalah orang Yahudi, yang memerlukan penjelasan mengapa Kerajaan Allah yang dinantikan di bumi belum juga tiba, karena Mesias sudah datang. Matius menulis Injil untuk menjelaskan tentang Raja dan Kerajaan Allah kepada khalayak Yahudi. Dalam perkataan Tuhan Yesus yaitu "Aku diutus hanya kepada domba-domba yang hilang dari umat Israel", menunjukkan prioritas kedatangan Yesus bagi kalangan Israel, karena mereka itulah yang sedang menantikan Kerajaan bahagia, sebagaimana telah dijanjikan kepada mereka dari dahulu kala. Matius memakai kata "Kerajaan" sebanyak 50 kali di dalam penulisannya, dan kata ini merupakan kata kunci dalam Injil Matius. Setelah janji itu ditawarkan dan diberikan kepada orang-orang Yahudi, namun secara nasional Yahudi menolak Mesias mereka.

Setelah mereka menolak Dia, maka Yesus mulai berbicara tentang "jemaat-Ku", seperti yang terdapat di dalam Matius 16:18 yang dalam bahasa Yunani disebut "ekklesia" yang mengandung pengertian "mereka yang dipanggil keluar", yakni mereka yang percaya kepada Dia dalam kerajaan-Nya kelak. Dengan penolakan orang-orang Yahudi atas Mesias yang dijanjikan itu, maka Yesus membukanya kepada orang-orang kafir, dengan suatu program rahasia, yaitu mereka yang berada di luar garis keturunan Israel akan memperoleh kasih karunia Allah atau anugerah keselamatan telah terbuka bagi semua bangsa.

Sejak orang Yahudi menolak Yesus sebagai Mesias dan Raja yang hendak mendirikan kerajaan di bumi, maka kesempatan diberikan kepada orang kafir dalam tugas penyelenggaraan kasih karunia Allah. Dengan demikian, jelas sekali terlihat sifat atau ciri keyahudian dalam Injil Matius. Akan tetapi Injil ini juga sekaligus memberikan semacam penegasan bahwa karena sekarang mereka telah menolak Mesias, maka tidak mengherankan apabila sekarang janji itu "dibagi" kepada bangsa-bangsa non-Yahudi.

Konteks Matius 1-2 (2:1-12). Sekali lagi dalam dua pasal ini kita melihat betapa kuatnya unsur-unsur PL. Penulis (Matius Lewi) memulai Injilnya dengan silsilah Yesus dengan menyebut Yesus sebagai anak Daud, anak Abraham. Mengapa? Matius menyebut Yesus sebagai anak Daud, hendak menunjukkan bahwa Yesus adalah keturunan raja. Bahkan Yesus menggunakan istilah atau nama raja agung ini sebanyak 17 kali dalam injil ini. Hampir dapat dipastikan bahwa gelar anak Daud merupakan gelar mesianik. Daud merupakan raja yang termasyur dalam sejarah kerajaan bangsa Israel. Hal ini disebabkan karena Daud merupakan pejuang yang dahsyat, sehingga gelar ini merujuk kepada mesias penakluk yang

\footnotetext{
${ }^{4}$ Bandingkan penjelasan Morris, hlm. 3.

${ }^{5}$ Ekklēsia, derived via $e k$-kaleo which was used for the summons to the army to assemble, from kaleō, to call. Thus ekklessia, centuries before the translation of the OT and the time of the NT, was clearly characterized as a political phenomenon, repeated according to certain rules and within a certain framework. (Sumber: The New International Dictionary of New Testament Theology Volume 1 A-F, Zondervan, Grand Rapids, Michigan, 1986, hlm. 291).
} 
akan menghancurkan musuh-musuh Israel dan pada saat yang bersamaan menegakkan kerajaan Allah dengan Yerusalem sebagai ibukotanya.

Pemakaian istilah anak Daud dalam konteks ini hendak menunjukkan arti Mesias dari keturunan Daud. Dan yang membuat hal ini menjadi menarik adalah ketika Matius paling sering menggunakan istilah ini ketika orang-orang sedang datang kepada Yesus meminta tolong $(9: 27 ; 15: 22 ; 20: 30-31)$. Namun istilah anak Daud juga muncul dalam arak-arakan masuknya Yesus ke Yerusalem $(21: 9,15)$, yang menunjukkan Matius bukannya tidak menyadari aspek rajawi atau mesianik dari istilah ini. Injil Matius adalah tentang Dia yang menggenapi segala sesuatu yang dimaksudkan bagi keturunan Raja Israel terbesar. ${ }^{6}$

Yesus juga disebut dalam silsilah itu sebagai anak Abraham, di mana janji-janji (covenan) untuk pertama kali diberikan dan dapat dikatakan secara 'sakral' dimulai. Dengan Abrahamlah Allah membuat kovenan yang memisahkan Israel untuk menjadi umat Allah dalam pengertian yang khusus (Kej. 12:2-3; 15:17-21; 17:1-14). ${ }^{7}$ Bahkan dapat dikatakan bahwa orang Israel bermegah karena mereka adalah keturunan Abraham. Nama Abraham dalam bahasa Ibrani berarti "bapa sejumlah besar bangsa" (Kej. 17:5) bahkan telah dinubuatkan bahwa bangsa-bangsa akan mendapatkan berkat melalui Abraham (Kej. 12:3). ${ }^{8}$

Dengan memunculkan dan mengkombinasikan anak Daud dan anak Abraham, Matius sebenarnya sedang menunjukkan dua alur keturunan Ibrani Yesus dan mengimplikasikan bahwa Yesus menggenapi segala yang bisa diharapkan di dalam diri seorang Mesias yang memiliki hubungan seperti itu. Oleh karena pada zaman dahulu Tuhan telah memberikan sebuah janji yang juga memiliki sifat mesianik cukup kuat seperti yang tercatat dalam 2 Samuel 7:12-13, "Apabila umurmu sudah genap dan engkau telah mendapat perhentian bersama-sama dengan nenek moyangmu, maka Aku akan membangkitkan keturunanmu yang kemudian, anak kandungmu, dan Aku akan mengokohkan kerajaannya. Dialah yang akan mendirikan rumah bagi nama-Ku dan Aku akan mengokohkan takhta kerajaannya untuk selama-lamanya". Hal itu pun ditegaskan oleh Penulis dalam 2: 2 "Raja Orang Yahudi"; 2: 4 "Mesias"; hingga kutipan Mikha 5:1 dalam ayat 6. Selain itu, Bethlehem tanah Yudea juga menunjukkan identitas Yesus sebagai keturunan Yehuda.

Lalu Mengapa dalam 2:1-12, penulis menulis kisah tentang orang Majus yang juga datang mengunjungi Yesus? Sekali lagi, di sini sesuai dengan konteks Injil Matius bahwa meskipun injil ini sangat identik dengan Yudaisme, akan tetapi sekaligus hendak menyadarkan bahwa karena mereka telah menolak Mesias, makanya kemudian berkat itu diberikan kepada bangsa-bangsa non-Yahudi.

Hal-hal yang jelas dikemukakan dalam 2:1-12. Perhatikan bagan di bawah ini!

\begin{tabular}{|l|ll|l|}
\hline Ayat 1 & $\begin{array}{l}\text { Yesus lahir di Bethlehem di tanah Yudea } \\
- \\
\text { Pada zaman Herodes } \\
\text { Orang-orang Majus dari Timur mengunjungi bayi Yesus yang baru saja } \\
\text { lahir. }\end{array}$ \\
\hline Ayat 2 & $\bullet$ & Orang-orang Majus itu mencari-cari di manakah tempat Yesus \\
\hline
\end{tabular}

${ }^{6}$ Baca juga apa yang dikemukakan oleh G. Dalman dalam diskusi tentang istilah "Anak Daud" dalam buku The Words of Jesus (Edinburgh, 1902), hlm. 316-24. Lihat juga penjelasan Morris dalam buku New Testament Theology, hlm. 126-27.

${ }^{7}$ Morris, hlm. 21.

${ }^{8}$ Morris, hlm. 22. 


\begin{tabular}{|c|c|}
\hline & $\begin{array}{l}\text { dilahirkan. } \\
\text { - Dalam narasi itu, Yesus disebut raja orang Yahudi. } \\
\text { - Orang Majus melihat petunjuk itu dengan bintang di langit. }\end{array}$ \\
\hline Ayat 3 & $\begin{array}{l}\text { - Herodes terkejut mendengar berita yang disampaikan oleh orang Majus. } \\
\text { - Bahkan penduduk Yerusalem pun juga demikian. }\end{array}$ \\
\hline Ayat 4-6 & $\begin{array}{l}\text { - Herodes mengumpulkan semua imam kepala dan Ahli Taurat dan } \\
\text { menanyakan tentang kelahiran dan di mana Mesias akan dilahirkan. } \\
\text { - Informasi dari mereka: "Mesias akan lahir di Betheleham di tanah } \\
\text { Yudea". } \\
\text { - Kelahirannya itu sudah sesuai dengan nubuat para nabi dalam PL, } \\
\text { seperti dalam Mikha 5:1. }\end{array}$ \\
\hline Ayat 7-8 & $\begin{array}{l}\text { - Herodes dengan diam-diam memanggil orang majus itu kemudian } \\
\text { berdiskusi dengan mereka. } \\
\text { - Herodes memerintahkan supaya mereka pergi mengunjungi anak itu, } \\
\text { setelah mereka menemukan tempatnya, Herodes minta supaya } \\
\text { diberitahukan kepadanya. }\end{array}$ \\
\hline Ayat 9-12 & $\begin{array}{l}\text { - Orang Majus berangkat ke Bethlehem dengan tuntunan bintang di langit. } \\
\text { Mereka berangkat dengan sukacita yang besar. } \\
\text { - Mereka menemukan tempatnya, lalu masuk dan melihat Anak itu } \\
\text { Bersama ibunya, Maria - sambal sujud menyembahnya. } \\
\text { - Mereka pun mempersembahkan emas, kemenyan, dan mur kepada bayi } \\
\text { itu. } \\
\text { - Mereka juga mendapatkan peringatan dalam mimpi supaya tidak } \\
\text { kembali kepada Herodes. } \\
\text { - Sehingga mereka pulang melalui jalan yang lain. }\end{array}$ \\
\hline
\end{tabular}

Siapa saja yang muncul dalam perikop 2:1-12? Pertama adalah Yesus. Di mana dalam perikop ini Dia disebut sebagai Raja orang Yahudi (ay. 2), Mesias (ay. 4), Seorang pemimpin, yang akan menggembalakan umat-Ku Israel, Anak ${ }^{9}$ (ay. 8, 9, 10). Hal yang menarik di sini adalah ungkapan orang-orang Majus yang menyebut bahwa yang lahir itu adalah raja orang Yahudi. Dalam pengertian bahwa itu berarti "raja yang lahir" bukan "lahir untuk menjadi raja". Sehingga dapat dipahami bahwa orang Majus berbicara tentang siapa Yesus bukan akan menjadi apa Yesus. Yang pasti adalah istilah raja dalam konteks ini memiliki sifat yang identik dengan istilah Mesias.

Selanjutnya, Yesus juga disebut sebagai seorang pemimpin yang akan menggembalakan umat-Ku, Israel. Pemimpin memang tidak disebut akan menjadi Mesias, tetapi seorang yang akan menggembalakan umat jelas memenuhi syarat untuk disebut sebagai Mesias. Kata menggembalakan memang seringkali digunakan untuk menunjuk apa yang para

${ }^{9}$ Kata yang diterjemahkan sebagai Anak bisa dipakai untuk menunjuk anak dalam segala usia, tetapi umumnya untuk menunjuk anak yang masih kecil. Dan dalam konteks perikop ini, kata ini jelas merujuk kepada anak yang masih sangat kecil. Dalam perikop ini menggunakan istilah paidion yang merupakan bentuk turunan dari pais. Dan Matius menggunakan istilah itu sebanyak 18 kali. 
gembala lakukan terhadap sekumpulan ternak (1Kor. 9:7) namun secara simbolis, kata ini menekankan perhatian sang pemimpin di saat mengawasi mereka yang dia pimpin. ${ }^{10}$

Kedua adalah orang Majus dari Timur. Siapakah mereka? Berapakah jumlah mereka? Mungkin kedua pertanyaan ini cukup signifikan untuk dijawab dalam eksposisi ini. Untuk pertanyaan pertama, orang Majus bukanlah orang-orang yang berhikmat dalam pengertian umum, tetapi mereka yang mempelajari perbintangan. Mereka adalah orang Persia (tapi kemudian Babel), yang ahli dalam astronomi atau ahli perbintangan, tafsir mimpi. Mereka berasal dari Timur. Ini merupakan istilah umum yang digunakan untuk menunjuk orangorang yang berasal dari Babel. Melalui ilmu perbintangan yang mereka ketahui, mereka dapat menemukan petunjuk bahwa ada raja yang lahir di Yudea.

Kemudian untuk pertanyaan yang kedua, perlu diketahui bahwa dalam tradisi memang akrab menganggap bahwa orang Majus itu ada tiga orang. Meskipun dalam narasi Matius tidak disebutkan sama sekali. Munculnya angka tiga ini tampaknya dideduksi dari jumlah persembahan yang mereka bawa. Akan tetapi, sepertinya sulit untuk menerima bahwa mereka hanya tiga orang saja, mengingat mereka menempuh perjalanan yang cukup jauh dan kemudian mereka pun membawa harta benda yang cukup berharga (emas, kemenyan dan mur) untuk dipersembahkan kepada Yesus. Sehingga apabila mereka hanya tiga orang saja, akan menjadi cukup riskan, karena bisa saja mereka akan dirampok di jalan yang mereka lalui.

Ketiga adalah Herodes. Herodes ini adalah Herodes Agung. Ia adalah seorang Edom, bukan orang Yahudi. Dia disebut "raja", maksudnya raja wilayah, karena dia diangkat menjadi raja oleh kekaisaran Romawi, menjadi Raja Yudea pada tahun 40 SM. Dia merupakan pemimpin yang dictator yang tidak mengindahkan moral, tetapi yang menarik adalah dia dijuluki "agung" karena keberhasilan. Mungkin karena dia berhasil membangun kembali Bait Suci di Yerusalem dan kota Samaria.

Keempat adalah para imam dan Ahli Taurat. Para imam bisa saja merujuk kepada ketua pengawal bait suci, ketua pelaksana harian dan mingguan para imam, dan mereka yang bertanggung jawab atas urusan keuangan, dll. Ahli Taurat bisa merujuk kepada sekretaris atau juru tulis, tetapi bisa pula kepada seorang yang ahli di bidang hukum. Dalam konteks Injil Matius, imam memang seringkali disandingkan dengan ahli Taurat. Dan yang terakhir adalah Maria. Ibu Yesus, atau yang dalam perikop ini disebut ibu Anak itu (ay. 11).

Apa saja yang dikisahkan dalam perikop ini? Berikut ini beberapa point penting dalam urutan cerita atau deskripsi penulis, yakni: (1) Orang Majus itu mencari-cari di mana Yesus dilahirkan adalah supaya mereka dapat menyembah-Nya dengan memberikan persembahan kepada-Nya. (2) Orang Majus bertanya kepada Herodes karena memang dalam perspektif mereka yang lahir itu adalah raja, maka referensi mereka adalah Herodes karena pada waktu itu dia adalah raja di tanah Yudea di Yerusalem. (3) Akan tetapi justru mereka dapat menemukan tempat anak itu dilahirkan melalui tuntunan bintang. (4) Penyembahan orang Majus kepada bayi Yesus ditandai dengan mempersembahkan emas, kemenyan dan mur. (5) Peringatan dalam mimpi ini memiliki sifat yang ilahi. Karena dalam injil Matius memang seringkali perintah ilahi itu diberikan melalui mimpi (1:20).

Kapan kisah ini terjadi? Apabila membaca perikop ini, khususnya pada ayat 1 , maka di sana jelas kita memperoleh informasi bahwa itu terjadi pada zaman raja Herodes. Dan seperti yang telah dijelaskan di atas bahwa yang dimaksud di sini adalah Herodes Agung.

\footnotetext{
${ }^{10}$ Bandingkan Morris, hlm. 42.
} 
Di manakah Yesus dilahirkan? Jawabannya adalah di Bethlehem, di Yudea (tanah Yehuda) hendak membedakan Bethlehem tempat Yesus lahir dengan Bethlehem yang ada di Galilea (Yos. 19:15). Apa yang hendak ditekankan? Intinya, bahwa di sini hendak menekankan bahwa Yesus lahir di kota kerajaan, tempat Raja Agung Daud dilahirkan. Ini merupakan salah satu cara Matius untuk menekankan kemesiasan Yesus.

Mengapa Yesus lahir di Bethlehem? Mengapa harus orang Majus? Mengapa orang Majus bertanya kepada Herodes? Mengapa Herodes meminta orang Majus supaya memberitahukan tempat di mana anak itu apabila mereka sudah menemukan tempatnya? Mengapa orang Majus tidak kembali lagi kepada Herodes setelah menemukan tempat Anak itu? Jawaban untuk beberapa pertanyaan di atas akan diuraikan sebagai berikut. (1) Yesus lahir di Bethlehem untuk menekankan bahwa Dia adalah raja atau Mesias, keturunan Daud. (2) Orang Majus melambangkan orang-orang non-Yahudi yang memperoleh anugerah atas kelahiran Yesus. Ini menjadi salah satu ciri khas Injil Matius yang juga menekankan tentang keselamatan bagi bangsa-bangsa lain. (3) Orang Majus melihat bahwa anak yang akan lahir adalah raja. Dan pada waktu itu, Herodes yang adalah raja di tanah Yudea. Itulah sebabnya mereka bertanya kepadanya. (4) Herodes berniat untuk membunuh bayi Yesus. Karena Herodes sadar bahwa dengan lahirnya anak itu maka posisinya sebagai raja orang Yahudi menjadi terancam. (5) Orang Majus tidak kembali karena telah mendapat peringatan dari Tuhan supaya tidak kembali ke Herodes. Karena Tuhan tahu maksud jahat dari Herodes.

Bagaimana caranya orang Majus dapat menemukan tempat Yesus dilahirkan? Sebenarnya dalam perikop ini diceritakan dengan jelas bahwa orang Majus hanya memperoleh dua petunjuk dari Tuhan, yakni: (1) petunjuk melalui bintang di langit; dan (2) petunjuk dari para imam dan ahli Taurat. Oleh karena dari merekalah diperoleh informasi bahwa Yesus lahir di Bethlehem, tanah Yudea.

\section{Interpretasi}

Apa yang hendak disampaikan oleh perikop ini untuk pembacanya waktu itu? Ingat pembaca Injil Matius adalah orang Yahudi, yang memerlukan penjelasan mengapa Kerajaan Allah yang dinantikan di bumi telah tiba, karena Mesias sudah datang.

Yesus adalah Raja orang Yahudi = Mesias. Matius hendak menyampaikan bahwa Yesus adalah Raja orang Yahudi yang jauh lebih Agung dari pada Herodes Agung. Yesus adalah penggenapan nubuat para nabi dalam Perjanjian Lama. Seperti dalam perikop ini, khususnya ayat 6 , menunjukkan bahwa kelahirannya menggenapi nubuat nabi Mikha. Yesus adalah keturunan Daud dan mewarisi tahkta Daud yang dulu pernah Tuhan janjikan bahwa keturunannya akan menjadi raja sampai selama-lamanya. Itulah sebabnya Dia dilahirkan di Bethlehem, kota Daud. Raja berarti Mesias. Mesias adalah tokoh atau figur pemimpin yang dimunculkan Allah untuk membebaskan umat-Nya dan memimpin umat-Nya untuk kembali kepada Allah.

Orang Majus = bangsa-bangsa lain memperoleh anugerah dari Tuhan. Meskipun mereka bukanlah orang Yahudi namun Tuhan memakai mereka untuk menyambut kelahiran Yesus Kristus. Sebenarnya ini bisa menjadi "sindiran" bagi orang Yahudi, yang terlalu eksklusif dengan statusnya sebagai umat Allah. Ternyata Tuhan dapat memakai bangsa lain untuk menjadi atau memberikan kemuliaan bagi-Nya. Ketika umat-Nya sendiri seolah-olah tidak mengenal bahkan menolaknya, Dia membangkitkan bangsa lain untuk menjadi penyembah-penyembahnya. 
Herodes, Para Imam dan Ahli Taurat = Sikap Orang Yahudi merespons kelahiran Rajanya. Meskipun Herodes Agung bukan orang Yahudi namun karena dia diangkat sebagai raja orang Yahudi, maka dalam hal ini dia mewakili orang Yahudi. Sehingga sikapnya mewakili orang-orang Yahudi. Tetapi imam-imam dan ahli-ahli Taurat yang tahu banyak tentang Firman Tuhan / Mesias ini, tidak mau pergi ke Betlehem untuk mencari Mesias.

\section{Aplikasi: Tiga Sikap terhadap kelahiran Yesus}

Pertama, kehadiran Tuhan Yesus 'mengganggu' kehidupannya / kedudukannya sehingga ia menentang Tuhan Yesus dan ingin membunuhNya. Perlu diketahui bahwa orang yang memusuhi Yesus belum tentu memusuhi gereja. Herodes membangun Bait Allah, tetapi ia memusuhi Yesus. Jadi bisa saja saudara pro pada gereja / kekristenan, tetapi saudara memusuhi Yesus.

Kedua, imam-imam dan ahli-ahli Taurat yang tahu banyak tentang Firman Tuhan / Mesias ini, tidak mau pergi ke Betlehem untuk mencari Mesias. Mereka acuh tak acuh terhadap diri Tuhan Yesus sendiri. Banyak orang Kristen yang mempunyai jabatan tinggi dalam gereja / sudah melayani Tuhan, mengerti banyak tentang Firman Tuhan, tetapi tidak mempunyai hubungan pribadi dengan Tuhan, dan tidak pernah 'datang' kepada Yesus. Mereka punya interest terhadap segala sesuatu dalam gereja (pendetanya, aliran gerejanya, aktivitasnya, jemaatnya, dsb) tetapi mereka acuh tak acuh terhadap diri Yesus sendiri.

Ketiga, awalnya Tuhan memberi petunjuk melalui 'bintang' (ay. 2) dan mereka taati. Kemudian Tuhan memberi petunjuk melalui Firman Tuhan yang diberikan oleh imam-imam dan ahli-ahli Taurat (ay 5-6) dan mereka tetap mentaati petunjuk ini. Tuhan memberi petunjuk dengan bintang lagi (ay 9-10), mereka tetap mentaatinya. Terakhir Tuhan memberi petunjuk melalui mimpi (ay 12), dan mereka juga mentaatinya.

Apakah aplikasinya? Kalau kita mendengar / belajar Firman Tuhan dan lalu mentaatinya, maka Tuhan akan memberi tambahan pengetahuan tentang Firman Tuhan. Tetapi sebaliknya, kalau kita belajar Firman Tuhan dan lalu mengabaikannya, maka lambat atau cepat Tuhan akan berhenti mengajarkan kebenaran kepada saudara. Karena itu, jadilah pelaku Firman (Yak. 1:22).

\section{Kesimpulan}

1. Yesus lahir di Bethelem, tanah Yudea untuk menegaskan bahwa Dia adalah keturunan Daud atau Dia adalah Raja. Bukan raja yang biasa, melainkan raja yang agung bahkan lebih agung dari Herodes Agung, karena dia adalah Mesias.

2. Tuhan memakai orang Majus untuk menyembah dan menyambut kelahiran Kristus hendak memperlihatkan bahwa Tuhan bisa memakai siapa saja untuk memuliakan Dia, meskipun umat-Nya sendiri telah menolaknya.

3. Herodes menyadari bahwa posisinya terancam. Oleh karena berdasarkan konfirmasi dari para imam dan ahli Taurat, anak yang lahir itu bukan raja biasa melainkan Mesias. Itulah sebabnya dia hendak membunuhnya, tanpa dia sadari bahwa Tuhan jauh lebih berkuasa. 